\title{
Isotopic Tracer Studies of Reaction Pathways for Propane Oxidative Dehydrogenation on Molybdenum Oxide Catalysts
}

\author{
Kaidong Chen, Enrique Iglesia,* and Alexis T. Bell* \\ Chemical and Materials Sciences Divisions, Lawrence Berkeley National Laboratory, and \\ Department of Chemical Engineering, University of California, Berkeley, California 94720-1462
}

Received: June 12, 2000

\begin{abstract}
Kinetic analysis and isotopic tracer studies were used to identify the elementary steps and their reversibility in the oxidative dehydrogenation of propane over $\mathrm{ZrO}_{2}$-supported $\mathrm{MoO}_{x}$ catalysts. Competitive reactions of $\mathrm{C}_{3} \mathrm{H}_{6}$ and $\mathrm{CH}_{3}{ }^{13} \mathrm{CH}_{2} \mathrm{CH}_{3}$ showed that propene is the most abundant primary product, and that $\mathrm{CO}$ and $\mathrm{CO}_{2}$ are formed via either secondary combustion of propene, or by direct combustion of propane. A mixture of $\mathrm{C}_{3} \mathrm{H}_{8}$ and $\mathrm{C}_{3} \mathrm{D}_{8}$ undergoes oxidative dehydrogenation without forming $\mathrm{C}_{3} \mathrm{H}_{8-x} \mathrm{D}_{x}$ mixed isotopomers, suggesting that steps involving $\mathrm{C}-\mathrm{H}$ bond activation are irreversible. Normal kinetic isotopic effects $\left(k_{\mathrm{C}-\mathrm{H}} / k_{\mathrm{C}-\mathrm{D}}\right)$ were measured for propane dehydrogenation (2.3), propane combustion (1.6) and propene combustion (2.1). These data indicate that the kinetically relevant steps in propane dehydrogenation and propene combustion involve the dissociation of $\mathrm{C}-\mathrm{H}$ bonds in the respective reactant. $\mathrm{H}-\mathrm{D}$ exchange occurs readily between $\mathrm{C}_{3} \mathrm{H}_{6}$ and $\mathrm{D}_{2} \mathrm{O}$ or $\mathrm{C}_{3} \mathrm{D}_{6}$ and $\mathrm{H}_{2} \mathrm{O}$, suggesting that $\mathrm{OH}$ recombination steps are reversible and quasi-equilibrated. Reactions of ${ }^{18} \mathrm{O}_{2} / \mathrm{C}_{3} \mathrm{H}_{8}$ on supported $\mathrm{Mo}^{16} \mathrm{O}_{x}$ species lead to the preferential initial appearance of lattice ${ }^{16} \mathrm{O}$ atoms in $\mathrm{H}_{2} \mathrm{O}, \mathrm{CO}$, and $\mathrm{CO}_{2}$, indicating that lattice oxygen is required for $\mathrm{C}-\mathrm{H}$ bond activation and for the ultimate oxidation of the adsorbed products of this reaction. ${ }^{18} \mathrm{O}^{16} \mathrm{O}$ was not detected during reactions of $\mathrm{C}_{3} \mathrm{H}_{8}-{ }^{18} \mathrm{O}_{2}-$ ${ }^{16} \mathrm{O}_{2}$ mixtures, consistent with irreversible $\mathrm{O}_{2}$ dissociation steps. These isotopic tracer results are consistent with a Mars-van Krevelen redox mechanism in which two lattice oxygens participate in the irreversible activation of $\mathrm{C}-\mathrm{H}$ bond in propane. The resulting alkyl species desorb as propene, and the remaining $\mathrm{O}-\mathrm{H}$ group recombines with neighboring $\mathrm{OH}$ groups to form water and reduced Mo centers. The reduced Mo centers finally reoxidize by irreversible dissociative chemisorption of $\mathrm{O}_{2}$. The proposed reaction mechanism leads to a complex kinetic rate expression that accurately describes the observed dependences on the partial pressure of propane, oxygen, and water.
\end{abstract}

\section{Introduction}

The oxidative dehydrogenation $(\mathrm{ODH})$ of propane has been investigated as a potential route to propene. ${ }^{1-7}$ Extensive evaluations of catalyst compositions have shown that the most active and selective ones contain $\mathrm{V}$ or Mo oxides as the active component. ${ }^{3}$ Over these catalysts, it has been proposed that the oxidation of propane occurs via parallel and sequential oxidation steps (Scheme 1). ${ }^{3}$

Propene is the primary product and carbon oxides $\left(\mathrm{CO}_{x}\right)$ form as byproducts via propane and propene combustion. Several studies have addressed the primary and secondary reactions occurring during propane $\mathrm{ODH},{ }^{8-15}$ but only a few of them have provided descriptions of the elementary steps involved or evaluations of the rate coefficients for the elementary steps. By analogy with other oxidation reactions, propane ODH has been proposed to proceed via a Mars - van Krevelen mechanism, ${ }^{9,12-15}$ in which propane reacts with lattice oxygen in the catalyst and the resulting vacancies then react by dissociative adsorption of $\mathrm{O}_{2}$. This mechanistic interpretation has been based largely on agreement between proposed sequences of elementary steps and experimental reaction kinetics. Only limited independent evidence for specific elementary steps has been reported. ${ }^{13}$ Although kinetic rate expressions for oxidative dehydrogenation and combustion pathways can provide a basis for developing

* To whom correspondence should be addressed. E-mail: iglesia@cchem. berkeley.edu; bell@cchem.berkeley.edu.
SCHEME 1: Reaction Network for the Propane Oxidation Reactions

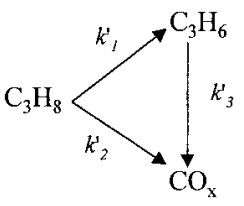

mechanistic inferences, they are insufficient to establish the identity and reversibility of individual elementary steps. Isotopic tracer studies, however, can discriminate among various mechanistic proposals that may describe with similar accuracy the measured rate expressions. Such studies can also confirm the assumptions required in order to obtain a given rate expression from a sequence of elementary steps. ${ }^{15,16}$

Vanadium-based catalysts have been widely studied as selective oxidation catalysts. ${ }^{3}$ Reaction mechanisms and detailed elementary steps for propane ODH on $\mathrm{VO}_{x}$ species have been proposed, and the reversibility of proposed elementary steps has been confirmed by isotopic tracer studies. ${ }^{15}$ Molybdenumbased catalysts have also been widely studied, but less thoroughly than vanadium-based catalysts, because of their lower ODH reaction rates. ${ }^{3}$ Some Mo-based catalysts, however, show very high propene selectivity..$^{3,4}$ Only a few studies have addressed the mechanism for alkane ODH reactions on Mobased catalysts but, to our knowledge, the detailed elementary steps have not been examined using isotopic methods or detailed 
TABLE 1: Characteristics of Various Mo-Zr Catalysts

\begin{tabular}{cccc}
\hline catalyst & $\begin{array}{c}\mathrm{MoO}_{3} \text { loading } \\
(\text { wt \% })\end{array}$ & $\begin{array}{c}\text { treatment } \\
\text { temp }(\mathrm{K})\end{array}$ & $\begin{array}{c}\text { Mo species } \\
\text { structure }\end{array}$ \\
\hline $\mathrm{MoO}_{x} / \mathrm{ZrO}_{2}$ & 11 & 773 & $\mathrm{MoO}_{x}$ oligomers \\
$\mathrm{MoO}_{3} / \mathrm{ZrO}_{2}$ & 37 & 673 & bulk $\mathrm{MoO}_{3}$ \\
$\mathrm{ZrMo}_{2} \mathrm{O}_{8} / \mathrm{ZrO}_{2}$ & 37 & 873 & bulk $\mathrm{ZrMo}_{2} \mathrm{O}_{8}$ \\
${ }^{a}$ Obtained by & $\mathrm{XRD}$, Raman, XAS, and UV-vis spectroscopy \\
characterization.
\end{tabular}

kinetic studies of the individual primary and secondary reactions involved. ${ }^{13,14}$

The structure and propane ODH properties of molybdate species supported on $\mathrm{ZrO}_{2}$ have been recently reported. ${ }^{4}$ The structure of $\mathrm{MoO}_{x}$ species on $\mathrm{ZrO}_{2}$ depends on the $\mathrm{MoO}_{x}$ surface density and on the temperature of thermal treatments. For Mo surface densities below $5 \mathrm{Mo} / \mathrm{nm}^{2}$, two-dimensional $\mathrm{MoO}_{x}$ oligomers form on $\mathrm{ZrO}_{2}$ surfaces, irrespective of treatment temperature. For higher $\mathrm{MoO}_{x}$ surface densities, treatment at low temperatures $(\sim 673 \mathrm{~K})$ leads to the formation of $\mathrm{MoO}_{3}$ crystallites, while treatment at high temperatures $(\sim 873 \mathrm{~K})$ causes the formation of $\mathrm{ZrMo}_{2} \mathrm{O}_{8}$ crystallites. Propane ODH turnover rate are widely different on $\mathrm{MoO}_{3}$ and $\mathrm{ZrMo}_{2} \mathrm{O}_{8}$ because of apparent differences in the strength and accessibility of active $\mathrm{Mo}=\mathrm{O}$ bonds. On both structures, the pseudo-firstorder rate constant for the combustion of propene is significantly higher than for propane ODH. ${ }^{4}$

The objective of this study is to determine the identity and reversibility of elementary steps involved in propane ODH on Mo-based catalysts and to infer the nature of the active surface species required to catalyze the rate-determining elementary steps. Isotopic tracer methods are combined with measurements of the concentration dependence for each reaction in Scheme 1. Most of the reported results were obtained on a $\mathrm{MoO}_{x} / \mathrm{ZrO}_{2}$ sample with a surface density of 3-4 Mo/nm $\mathrm{nm}^{2}$ and containing predominately two-dimensional $\mathrm{MoO}_{x}$ oligomers as the active species. Rate expressions were also obtained on two other $\mathrm{MoO}_{x} /$ $\mathrm{ZrO}_{2}$ samples containing predominately either $\mathrm{MoO}_{3}$ or $\mathrm{ZrMo}_{2} \mathrm{O}_{8}$ crystallites.

\section{Experimental Section}

Three $\mathrm{MoO}_{x} / \mathrm{ZrO}_{2}$ catalysts were used in the present study. These samples were prepared by incipient wetness impregnation of precipitated zirconium oxyhydroxide with an ammonium dimolybdate (99\%, Aldrich, Inc.) solution, followed by drying and thermal treatment in dry air. ${ }^{4}$ One sample contained $11 \mathrm{wt}$ $\% \mathrm{MoO}_{3}$ and it was treated in air at $773 \mathrm{~K}$. Structural characterization of this sample by X-ray diffraction and by X-ray absorption, Raman, and UV-visible spectroscopies indicated that Mo species exist predominantly as $\mathrm{MoO}_{x}$ oligormers. ${ }^{4}$ The other two samples contain $37 \mathrm{wt} \% \mathrm{MoO}_{3}$. One sample was treated in air at $673 \mathrm{~K}$ and the other at $873 \mathrm{~K}$. After treatment at $673 \mathrm{~K}$ this sample contains predominately $\mathrm{MoO}_{3}$ crystallites, while treatment at $873 \mathrm{~K}$ leads to the preferential formation of crystalline $\mathrm{ZrMo}_{2} \mathrm{O}_{8}$ structures. ${ }^{4}$ Table 1 shows the structural properties and designation for each of the $\mathrm{MoO}_{x} / \mathrm{ZrO}_{2}$ samples used in this study.

Reaction rates were measured using a quartz microreactor containing $0.02-0.1 \mathrm{~g}$ samples. ${ }^{5} \mathrm{C}_{3} \mathrm{H}_{8}$ and $\mathrm{O}_{2}$ conversions were varied by changing reactant flow rates between 0.8 and $3.5 \mathrm{~cm}^{3}$ $\mathrm{s}^{-1} \cdot \mathrm{C}_{3} \mathrm{H}_{8}$ and $\mathrm{O}_{2}$ conversions were typically below $2 \%$ and $20 \%$, respectively. Propane reaction rates were extrapolated to zero residence time in order to obtain initial dehydrogenation and combustion reaction, while propene combustion were obtained from the observed changes in propene selectivity with

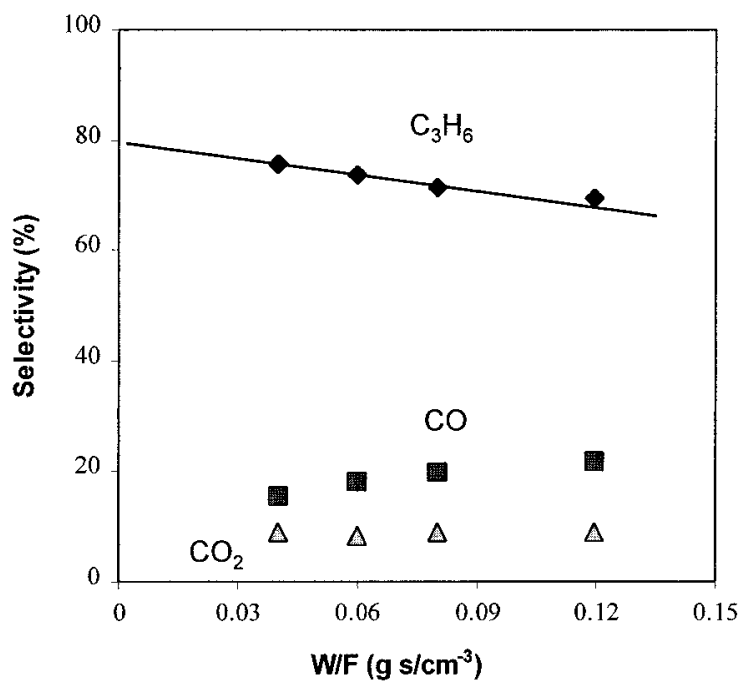

Figure 1. Dependence of products selectivity on bed residence time during $\mathrm{ODH}$ of propane $\left(\mathrm{MoO}_{x} / \mathrm{ZrO}_{2}, 703 \mathrm{~K}, 14 \mathrm{kPa}\right.$ of $\mathrm{C}_{3} \mathrm{H}_{8}, 1.7 \mathrm{kPa}$ of $\mathrm{O}_{2}$, balance $\mathrm{He}$ ).

residence time. ${ }^{5}$ Water was introduced into the $\mathrm{C}_{3} \mathrm{H}_{8}-\mathrm{O}_{2}$ reactants by reacting a metered $20 \% \mathrm{H}_{2} / \mathrm{Ar}$ side stream with $\mathrm{CuO}(150 \mathrm{~g}$ of $\mathrm{CuO})$ at $623 \mathrm{~K}$ to form the desired amount of $\mathrm{H}_{2} \mathrm{O}$. All transfer lines located down stream of the point of water introduction were kept above $393 \mathrm{~K}$ in order to prevent condensation.

All isotopic tracer studies were carried out in a gradientless batch reactor contained within a gas recirculation loop. ${ }^{17}$ Reactants and products were recirculated at $3.3 \mathrm{~cm}^{3} \mathrm{~s}^{-1}$ using a graphite gear micropump in order to maintain low propane conversions per pass $(<1 \%)$. The reactor was evacuated by mechanical and diffusion pumps isolated from the system by liquid nitrogen traps. The chemical and isotopic composition of reactants and products were measured by mass spectrometry after capillary gas chromatography (Hewlett-Packard model 5972 GC-MS). The deuterium and carbon-13 contents in the products were determined from mass spectrometric data using matrix techniques that correct for ion fragmentation and natural ${ }^{13} \mathrm{C}$ abundance. ${ }^{18}$ Undeuterated propane (Matheson, instrument purity $>99.5 \%$ ), perdeuterated propane (Isotec, chemical purity $>99.0 \%$, isotopic purity $>99.0 \%$ ), $2-{ }^{13} \mathrm{C}$-propane (Cambridge Isotopes, chemical purity $>98.0 \%$, isotopic purity $>99.0 \%$ ), propane-2,2- $d_{2}$ (Isotec, chemical purity $>99.0 \%$, isotopic purity $>99.0 \%$ ), ${ }^{18} \mathrm{O}_{2}$ (Isotec, isotopic purity $>99.0 \%$ ), ${ }^{16} \mathrm{O}_{2}$ (research grade, $>99.999 \%$ ), and propene (Matheson, C. P., >99.0\%) were used as reactants without further purification. Perdeuterated water $\left(\mathrm{D}_{2} \mathrm{O}\right.$; Isotec, chemical purity $>99.0 \%$, isotopic purity $>99.0 \%)$ and distilled water $\left(\mathrm{H}_{2} \mathrm{O}\right)$ were purified by several freeze-thaw evacuation cycles before use. Helium (research grade, $>99.999 \%$ ) was used as an inert diluent in all studies.

\section{Results and Discussion}

Reaction Network. Isotopic tracer and residence time studies have shown that propane reactions occur via a combination of parallel and sequential oxidation steps (Scheme 1) on $\mathrm{VO}_{x}$-based catalysts. ${ }^{15}$ Similar reaction pathways are suggested by residence time effects on propene selectivity observed on $\mathrm{MoO}_{x} / \mathrm{ZrO}_{2}$ (Figure 1). Propene selectivity decreases with increasing contact time, as it converts to $\mathrm{CO}_{x}$ via secondary combustion pathways. Propene selectivities extrapolated to zero residence time are less than $100 \%$, indicating that direct propane combustion reactions occur in parallel with ODH. Propene forms as the primary ODH product and $\mathrm{CO}_{x}$ forms via propene or propane combustion 


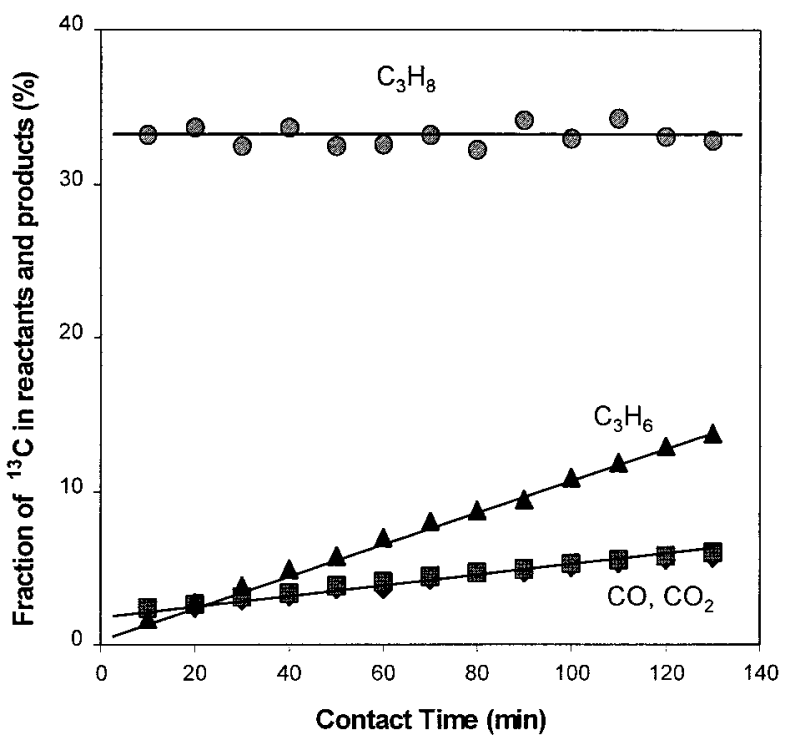

Figure 2. ${ }^{13} \mathrm{C}$ content in reaction products of propene/2-13 $\mathrm{C}$ propane/ $\mathrm{O}_{2}$ mixtures on $\mathrm{MoO}_{x} / \mathrm{ZrO}_{2}\left(688 \mathrm{~K}, 2.5 \mathrm{kPa}\right.$ of $\mathrm{C}_{3} \mathrm{H}_{8}-2-{ }^{13} \mathrm{C}, 0.5 \mathrm{kPa}$ of $\mathrm{C}_{3} \mathrm{H}_{6}, 1.7 \mathrm{kPa}$ of $\mathrm{O}_{2}$, balance $\mathrm{He}$, gradientless batch reactor).

steps. The rates of propane and propene reactions in Scheme 1 can be determined from the ${ }^{13} \mathrm{C}$ content in the products formed from mixtures of unlabeled propene and propane-2- ${ }^{13} C \cdot \cdot^{15,19-22}$ The ${ }^{13} \mathrm{C}$ content in the reactants and products is shown in Figure 2 for reactions of propane- $2-{ }^{13} \mathrm{C} /$ propene/oxygen mixture on $\mathrm{MoO}_{x} / \mathrm{ZrO}_{2}$. The ${ }^{13} \mathrm{C}$ fraction in propane remained at its initial value (0.33) throughout. Thus, the isotopic content in propane is not diluted by propene hydrogenation, as expected from the irreversible nature of the overall $\mathrm{ODH}$ reaction at the conditions of our study. The ${ }^{13} \mathrm{C}$ fraction in propene increases with contact time, because propene- $2-{ }^{13} \mathrm{C}$ is gradually formed from propane$2-{ }^{13} \mathrm{C}$ via dehydrogenation, at the same time as the propene isotopomers are consumed by combustion. The ${ }^{13} \mathrm{C}$ fractions in $\mathrm{CO}$ and $\mathrm{CO}_{2}$ were very similar, suggesting that the $\mathrm{CO}_{2} / \mathrm{CO}$ selectivity ratios in primary propane combustion and secondary propene combustion were very similar. However, the ${ }^{13} \mathrm{C}$ fraction in $\mathrm{CO}_{x}$ extrapolated to zero contact time is greater than 0 , suggesting that $\mathrm{CO}_{x}$ forms via both propane and propene combustion reactions. The reaction rate constant ratio $\left(k_{3}^{\prime} / k_{2}^{\prime}\right)$ for propene combustion $\left(k_{3}^{\prime}\right)$ to propane combustion $\left(k_{2}^{\prime}\right)$ can be calculated from the initial value of ${ }^{13} \mathrm{C}$ in $\mathrm{CO}_{x}$. The calculated $k_{3}^{\prime} / k_{2}^{\prime}$ value is 80 (based on the initial ${ }^{13} \mathrm{C}$ fraction in $\mathrm{CO}_{x}$ ). This value is very similar to the value of 87 calculated from the data in Figure 1 using the kinetic analysis procedures reported previously. ${ }^{4}$ Thus, these isotopic tracer results are consistent with the observed effects of reactor residence time on propene and $\mathrm{CO}_{x}$ selectivities, ${ }^{4,5,10-13}$ they confirm the parallel and sequential oxidation steps in ODH of propane over Mo-based catalysts.

Kinetic Dependence of Propane ODH Rates on $\mathrm{C}_{3} \mathrm{H}_{8}, \mathrm{O}_{2}$, and $\mathrm{H}_{2} \mathrm{O}$ Concentrations. The effects of varying the concentrations of $\mathrm{C}_{3} \mathrm{H}_{8}, \mathrm{O}_{2}$, and $\mathrm{H}_{2} \mathrm{O}$ on the initial rate of propene formation were determined. One kinetic rate expression was able to describe propane $\mathrm{ODH}$ rates on the three samples used in this study. This suggests that the elementary steps required for propane $\mathrm{ODH}$ reactions are similar on the surfaces of twodimensional $\mathrm{MoO}_{x}$ oligomers $\left(\mathrm{MoO}_{x} / \mathrm{ZrO}_{2}\right)$, bulk $\mathrm{MoO}_{3}\left(\mathrm{MoO}_{3} /\right.$ $\left.\mathrm{ZrO}_{2}\right)$, and bulk $\mathrm{ZrMo}_{2} \mathrm{O}_{8}\left(\mathrm{ZrMo}_{2} \mathrm{O}_{8} / \mathrm{ZrO}_{2}\right)$. Here, we show detailed data on $\mathrm{MoO}_{x} / \mathrm{ZrO}_{2}$. Figure 3 shows initial propene formation rates as a function of propane partial pressure at a given value of $\mathrm{O}_{2}$ partial pressure. Propene formation rates increased linearly with increasing propane partial pressure, in

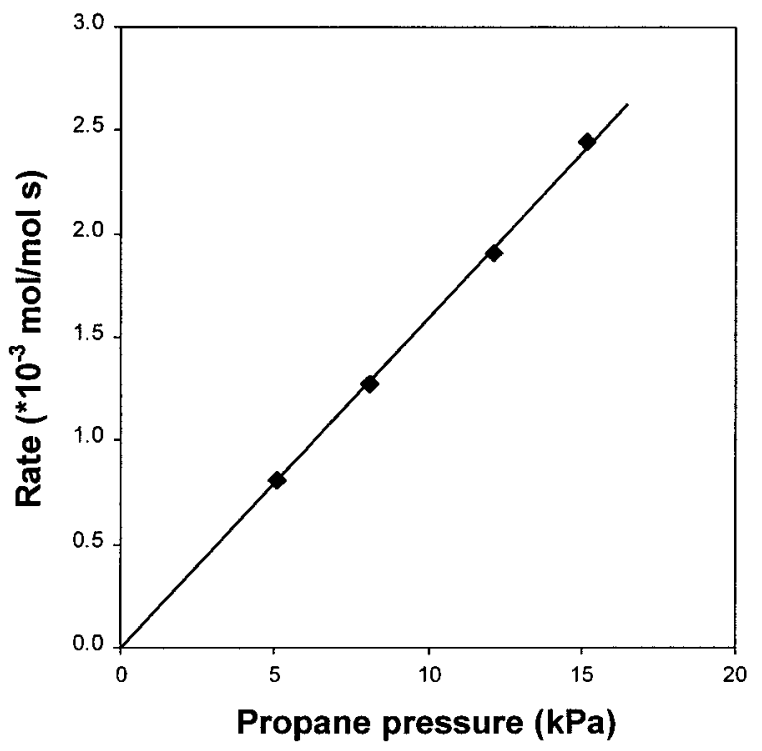

Figure 3. Effect of $\mathrm{C}_{3} \mathrm{H}_{8}$ pressure on $\mathrm{C}_{3} \mathrm{H}_{6}$ formation rate on $\mathrm{MoO}_{x} /$ $\mathrm{ZrO}_{2}\left(703 \mathrm{~K}, 1.3 \mathrm{kPa}\right.$ of $\mathrm{O}_{2}$, balance $\left.\mathrm{He}\right)$.

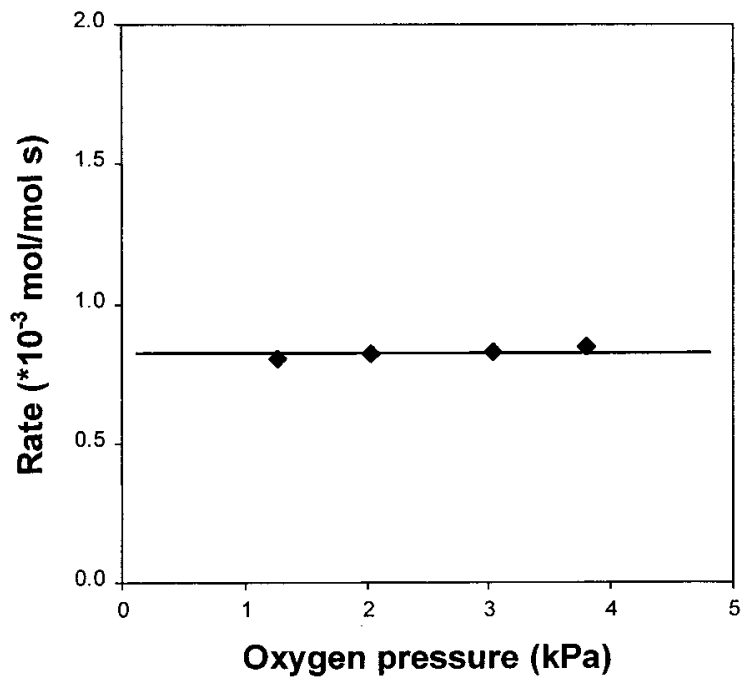

Figure 4. Effect of $\mathrm{O}_{2}$ pressure on $\mathrm{C}_{3} \mathrm{H}_{6}$ formation rate on $\mathrm{MoO}_{x}$ / $\mathrm{ZrO}_{2}\left(703 \mathrm{~K}, 5.1 \mathrm{kPa}\right.$ of $\mathrm{C}_{3} \mathrm{H}_{8}$, balance $\left.\mathrm{He}\right)$.

agreement with previous reports. ${ }^{11,13-15}$ Figure 4 shows that initial propene formation rates are independent of $\mathrm{O}_{2}$ partial pressure at a given propane partial pressure when $\mathrm{H}_{2} \mathrm{O}$ is not present in the $\mathrm{C}_{3} \mathrm{H}_{8} / \mathrm{O}_{2}$ feed, also in agreement with previous reports ${ }^{11-15}$ and suggesting a zero-order dependence on oxygen partial pressure. The effect of $\mathrm{H}_{2} \mathrm{O}$ partial pressure on initial propane ODH rates is shown in Figure 5 at constant $\mathrm{C}_{3} \mathrm{H}_{8}$ and $\mathrm{O}_{2}$ partial pressures. Water inhibits the rate of propane $\mathrm{ODH}$, in a manner similar to that reported previously for propane and ethane $\mathrm{ODH}$ over $\mathrm{V}_{2} \mathrm{O}_{5}$-based catalysts. ${ }^{15,23}$

Analysis of Elementary Steps. By analogy with our previous proposal on supported vanadia, ${ }^{15}$ the set of elementary steps below is used in order to describe the kinetic dependence of propene formation rates on $\mathrm{O}_{2}, \mathrm{C}_{3} \mathrm{H}_{8}$, and $\mathrm{H}_{2} \mathrm{O}$ for $\mathrm{MoO}_{x}$ catalysts. Propane ODH can be proposed based on the obtained kinetic power law rate expressions.

1. Nondissociative adsorption of propane by interaction on a lattice oxygen $\left(\mathrm{O}^{*}\right)$

$$
\mathrm{C}_{3} \mathrm{H}_{8}+\mathrm{O}^{*} \rightleftarrows \mathrm{C}_{3} \mathrm{H}_{8} \mathrm{O}^{*}
$$

2. $\mathrm{C}-\mathrm{H}$ bond activation by abstraction of $\mathrm{H}$ atom from adsorbed propane using a neighboring lattice oxygen atom 


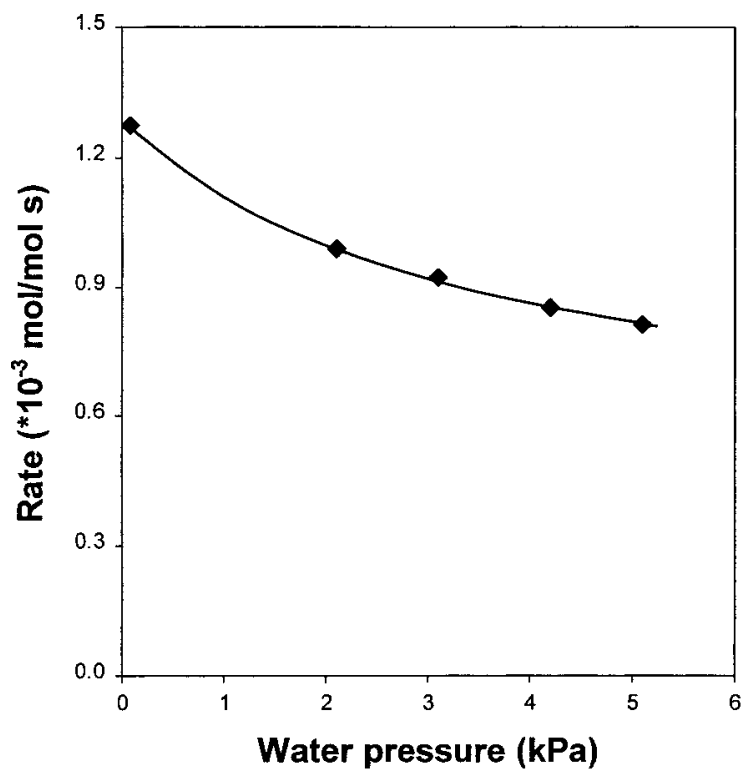

Figure 5. Effect of $\mathrm{H}_{2} \mathrm{O}$ pressure on $\mathrm{C}_{3} \mathrm{H}_{6}$ formation rate on $\mathrm{MoO}_{x} l$ $\mathrm{ZrO}_{2}\left(703 \mathrm{~K}, 8.1 \mathrm{kPa}\right.$ of $\mathrm{C}_{3} \mathrm{H}_{8}, 1.3 \mathrm{kPa}$ of $\mathrm{O}_{2}$, balance $\left.\mathrm{He}\right)$.

$$
\mathrm{C}_{3} \mathrm{H}_{8} \mathrm{O}^{*}+\mathrm{O}^{*} \rightarrow \mathrm{C}_{3} \mathrm{H}_{7} \mathrm{O}^{*}+\mathrm{OH}^{*}
$$

3. Desorption of propene by $\beta$-hydride elimination

$$
\mathrm{C}_{3} \mathrm{H}_{7} \mathrm{O}^{*} \rightarrow \mathrm{C}_{3} \mathrm{H}_{6}+\mathrm{OH}^{*}
$$

4. Recombination of $\mathrm{OH}$ groups to form water and a reduced Mo center $(*)$

$$
\mathrm{OH}^{*}+\mathrm{OH}^{*} \rightleftarrows \mathrm{H}_{2} \mathrm{O}+\mathrm{O}^{*}+*
$$

5. Reoxidation of Mo centers via dissociative chemisorption of $\mathrm{O}_{2}$

$$
\mathrm{O}_{2}+*+* \rightarrow \mathrm{O}^{*}+\mathrm{O}^{*}
$$

In this scheme, $\mathrm{O}^{*}$ is a lattice oxygen in $\mathrm{Mo}=\mathrm{O}$ or $\mathrm{Mo}-\mathrm{O}-$ Mo structures, $\mathrm{OH}^{*}$ is a hydroxyl group in $\mathrm{Mo}-\mathrm{O}-\mathrm{H}, \mathrm{C}_{3} \mathrm{H}_{7} \mathrm{O} *$ represents an adsorbed propoxide species bonded to a Mo cation through one of its $\mathrm{O}$ atoms $\left(\mathrm{Mo}-\mathrm{O}-\mathrm{C}_{3} \mathrm{H}_{7}\right)$, and $*$ represents a surface vacancy associated with either one $\mathrm{Mo}^{4+}$ or two $\mathrm{Mo}^{5+}$ cations in the $\mathrm{MoO}_{x}$ lattice.

The assumption of pseudo-steady state for all reaction intermediates leads to a complex rate expression, which can be made simpler by additional assumptions about the reversibility of specific elementary steps. Step 1 involves weak nondissociative adsorption of propane; the small expected binding energy of molecularly adsorbed propane is likely to lead to rapid reversible adsorption-desorption and to quasi-equilibration during propane ODH. Step 2 is assumed to be irreversible based on the low $\mathrm{C}_{3} \mathrm{H}_{8}-\mathrm{C}_{3} \mathrm{D}_{8}$ isotopic scrambling rates during $\mathrm{ODH}$ (shown below). The recombination of $\mathrm{OH}$ groups is assumed to be reversible and quasi-equilibrated, based on the observed inhibition by $\mathrm{H}_{2} \mathrm{O}$, which would not be possible if step 4 were irreversible, and on the results of $\mathrm{C}_{3} \mathrm{H}_{8}-\mathrm{D}_{2} \mathrm{O}$ exchange rate measurements during $\mathrm{ODH}$ reactions (shown below). $\mathrm{O}_{2}$ chemisorption is assumed to be irreversible based on the negligible rate of isotopic scrambling of ${ }^{16} \mathrm{O}_{2}-{ }^{18} \mathrm{O}_{2}$ mixtures during $\mathrm{ODH}$ reactions (shown below). Both in situ X-ray absorption and UV-visible spectroscopy showed that $\mathrm{MoO}_{x} / \mathrm{ZrO}_{2}$ catalysts remain essentially oxidized state during propane $\mathrm{ODH}$ and that concentration of oxygen vacancies is very low. ${ }^{24}$ The vacancy (*) concentration is likely to be much smaller than those of

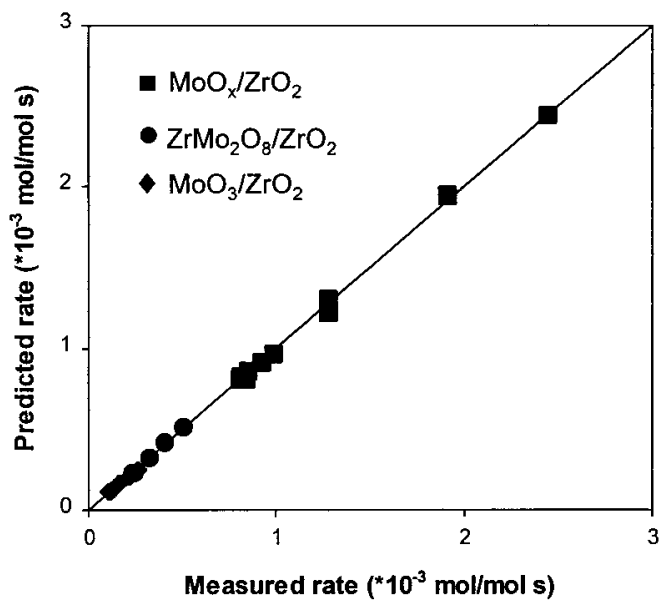

Figure 6. Comparison of predicted (from eq 6) and experimental $\mathrm{C}_{3} \mathrm{H}_{6}$ formation rates.

$\left(\mathrm{O}^{*}\right)$ and $\left(\mathrm{OH}^{*}\right)$ during propane $\mathrm{ODH}$. These assumptions lead to the kinetic rate expression

$$
r=\frac{K_{1} k_{2}\left[\mathrm{C}_{3} \mathrm{H}_{8}\right]}{\left[1+K_{1}^{0.25} k_{2}{ }^{0.25} K_{4}{ }^{-0.5} k_{5}{ }^{-0.25}\left[\mathrm{H}_{2} \mathrm{O}\right]^{0.5}\left[\mathrm{C}_{3} \mathrm{H}_{8}\right]^{0.25}\left[\mathrm{O}_{2}\right]^{-0.25}\right]^{2}}
$$

in which $k_{i}$ is the rate coefficient and $K_{i}$ is the equilibrium constant for reaction $i$. This equation predicts that the rate of propane $\mathrm{ODH}$ is first order in $\mathrm{C}_{3} \mathrm{H}_{8}$ concentration and zero order in the concentration of $\mathrm{O}_{2}$ at very low $\mathrm{H}_{2} \mathrm{O}$ concentrations. As the concentration of $\mathrm{H}_{2} \mathrm{O}$ increases, propane $\mathrm{ODH}$ rate decreases, and the apparent orders in $\mathrm{C}_{3} \mathrm{H}_{8}$ and $\mathrm{O}_{2}$ become smaller than unity and larger than zero, respectively. Figure 6 compares propane $\mathrm{ODH}$ rates predicted by this expression with rate data at various $\mathrm{C}_{3} \mathrm{H}_{8}, \mathrm{O}_{2}$, and $\mathrm{H}_{2} \mathrm{O}$ concentrations. The estimated rate coefficients are different for the three molybdena catalysts of this study, because these coefficients depend on the dispersion of the Mo oxide species and on the number of accessible sites. The excellent agreement shown in Figure 6 for all three catalysts, however, confirms the mechanistic resemblance of propane ODH reactions on $\mathrm{MoO}_{x}$ oligomers, bulk $\mathrm{MoO}_{3}$, and bulk $\mathrm{ZrMo}_{2} \mathrm{O}_{8}$. This is consistent with our previously proposed kinetic equivalence of $\mathrm{MoO}_{x}$ species at polymolybdate and bulk $\mathrm{MoO}_{3}$ surfaces. ${ }^{4}$ Alternate elementary steps, including propane interactions with surface vacancies and irreversible $\mathrm{OH}$ recombination steps, did not lead to rate expressions in satisfactory agreement with experimental rates.

Irreversible Initial $\mathbf{C}-\mathbf{H}$ Bond Activation in Propane. At very low $\mathrm{H}_{2} \mathrm{O}$ concentrations, the rate of propene formation depends linearly on $\mathrm{C}_{3} \mathrm{H}_{8}$ concentration, suggesting that propane activation is a kinetically relevant step. The reversibility of $\mathrm{C}-\mathrm{H}$ bond activation steps can be probed by measuring the rate of $\mathrm{H}-\mathrm{D}$ isotopic scrambling in "unreacted" propane during reactions of $\mathrm{C}_{3} \mathrm{H}_{8} / \mathrm{C}_{3} \mathrm{D}_{8}-\mathrm{O}_{2}$ mixtures. ${ }^{15}$ If the $\mathrm{C}-\mathrm{H}$ bond activation is reversible, $\mathrm{C}_{3} \mathrm{H}_{x} \mathrm{D}_{8-x}(0<x<8)$ isotopomers can form via the microscopic reverse of the $\mathrm{C}-\mathrm{H}$ bond activation step. ${ }^{19,20}$ If $\mathrm{C}-\mathrm{H}$ bond activation is irreversible, however, the formation of $\mathrm{C}_{3} \mathrm{H}_{x} \mathrm{D}_{8-x}(0<x<8)$ isotopomers will be much slower than propane conversion to propene and $\mathrm{CO}_{x} \cdot{ }^{15}$

Figure 7 shows the deuterium distribution in propane during the reaction of a $\mathrm{C}_{3} \mathrm{H}_{8} / \mathrm{C}_{3} \mathrm{D}_{8} / \mathrm{O}_{2}$ mixture over $\mathrm{MoO}_{x} / \mathrm{ZrO}_{2}$ at $\sim 4 \%$ propane conversion. At all propane conversions, only $\mathrm{C}_{3} \mathrm{H}_{8}$ and $\mathrm{C}_{3} \mathrm{D}_{8}$ were detected in the unreacted propane pool. No crossexchange $\mathrm{C}_{3} \mathrm{H}_{x} \mathrm{D}_{8-x}$ isotopomers were detected by mass spec- 


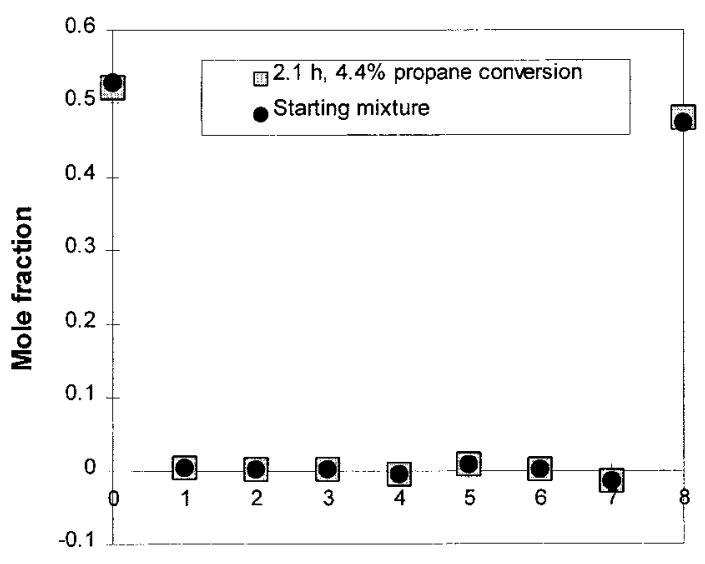

Number of deuterium atoms in propane

Figure 7. Deuterium cross exchange for $\mathrm{C}_{3} \mathrm{H}_{8} / \mathrm{C}_{3} \mathrm{D}_{8} / \mathrm{O}_{2}$ reactant mixture on $\mathrm{MoO}_{x} / \mathrm{ZrO}_{2}$. Deuterium distributions in reactant mixture and in "unreacted" propane $\left(688 \mathrm{~K}, 7.1 \mathrm{kPa}\right.$ of $\mathrm{C}_{3} \mathrm{H}_{8}, 7.1 \mathrm{kPa}$ of $\mathrm{C}_{3} \mathrm{D}_{8}, 1.7$ $\mathrm{kPa}$ of $\mathrm{O}_{2}$, balance $\mathrm{He}$, gradientless batch reactor).

trometry, suggesting that $\mathrm{C}-\mathrm{H}$ bond activation is an irreversible step in the ODH reaction sequence. The isotopomer distributions were determined using deconvolution methods that neglect secondary kinetic isotope effects in the fragmentation process. ${ }^{18}$ This deconvolution procedure can lead to very small negative values of some isotopomer mole fractions (e.g., $\mathrm{C}_{3} \mathrm{D}_{7} \mathrm{H}$ in Figure 7). The mole fractions of all mixed propane isotopomers are zero within the accuracy of the measurements and the reliability of the deconvolution procedures. These conclusions are similar to those reached for propane $\mathrm{ODH}$ reactions on $\mathrm{VO}_{x} / \mathrm{ZrO}_{2}{ }^{15}$

The kinetic relevance of $\mathrm{C}-\mathrm{H}$ (and $\mathrm{C}-\mathrm{D}$ ) bond dissociation steps can also be inferred from the effect of deuterium substitution on the rate of propene and $\mathrm{CO}_{x}$ formation. The reaction rate constants for ODH reactions of undeuterated $\left(\mathrm{C}_{3} \mathrm{H}_{8}\right)$ and perdeuterated $\left(\mathrm{C}_{3} \mathrm{D}_{8}\right)$ propane $\left(k_{\mathrm{C}-\mathrm{H}}^{\prime}\right.$ and $k_{\mathrm{C}-\mathrm{D}}^{\prime}$, respectively) were obtained from the initial rates of propene formation using $\mathrm{C}_{3} \mathrm{H}_{8}-\mathrm{O}_{2}$ or $\mathrm{C}_{3} \mathrm{D}_{8}-\mathrm{O}_{2}$ mixtures. Kinetic isotope effects for propane direct combustion and for secondary propene combustion can also be measured from the initial rates of $\mathrm{CO}_{x}$ formation and from the effect of residence time on propene selectivity for $\mathrm{C}_{3} \mathrm{H}_{8}-\mathrm{O}_{2}$ and $\mathrm{C}_{3} \mathrm{D}_{8}-\mathrm{O}_{2}$ mixtures. ${ }^{25}$

A rigorous analysis of the kinetic isotope effects requires that we treat the system using the reaction network of Scheme 1. At relatively low conversions and without external $\mathrm{H}_{2} \mathrm{O}$ addition, the rate of each of these reactions is well described by

$$
\begin{aligned}
& r_{1}=k_{1}^{\prime}\left[\mathrm{C}_{3} \mathrm{H}_{8}\right] \\
& r_{2}=k_{2}^{\prime}\left[\mathrm{C}_{3} \mathrm{H}_{8}\right] \\
& r_{3}=k_{3}^{\prime}\left[\mathrm{C}_{3} \mathrm{H}_{6}\right]
\end{aligned}
$$

where $k_{i}$ is the apparent first-order rate coefficient for reaction $i$. The propene selectivity at relatively low conversions in a batch reactor is given by ${ }^{5}$

$$
S=S^{0}\left(1-k_{3}^{\prime} C_{\mathrm{v}} t / 2\right)
$$

where $C_{\mathrm{v}}$ is the concentration of Mo atoms per unit reactor volume, $t$ is the reaction time in the batch reactor, and $S^{0}=$ $k_{1}^{\prime} /\left(k_{1}^{\prime}+k_{2}^{\prime}\right)$ is the initial propene selectivity (as $t$ goes to zero). The initial rate of propene conversion (as $t \rightarrow 0$ ) gives the value of $k_{1}^{\prime}$. The initial propene selectivity $\left(S^{0}\right)$ depends on the $k_{1}^{\prime} / k_{2}^{\prime}$
TABLE 2: Kinetic Isotopic Effects over 11 wt $\%$ MoO $_{x} /$ $\mathrm{ZrO}_{2}$ Catalyst $\left(688 \mathrm{~K}, 14.2 \mathrm{kPa}\right.$ of Propane, $1.7 \mathrm{kPa}$ of $\mathrm{O}_{2}$, Balance He)

\begin{tabular}{cccc}
\hline isotope & $\mathrm{CH}_{3} \mathrm{CH}_{2} \mathrm{CH}_{3}$ & $\mathrm{CH}_{3} \mathrm{CH}_{2} \mathrm{CH}_{3}$ & $\mathrm{CH}_{3} \mathrm{CD}_{2} \mathrm{CH}_{3}$ \\
\hline $\begin{array}{c}\mathrm{CD}_{3} \mathrm{CD}_{2} \mathrm{CD}_{3} \\
\mathrm{CH}_{3} \mathrm{CD}_{2} \mathrm{CH}_{3}\end{array}$ & $\mathrm{CD}_{3} \mathrm{CD}_{2} \mathrm{CD}_{3}$ \\
\hline $\begin{array}{c}k_{1, \mathrm{C}-\mathrm{H}}^{\prime} / k_{1, \mathrm{C}-\mathrm{D}}^{\prime} \\
\text { secondary combustion } \\
k_{3, \mathrm{C}-\mathrm{H}}^{\prime} / k_{3, \mathrm{C}-\mathrm{D}}^{\prime}\end{array}$ & 2.3 & 1.7 & 1.4 \\
$\begin{array}{c}\text { primary combustion } \\
k_{2, \mathrm{C}-\mathrm{H}}^{\prime} / k_{2, \mathrm{C}-\mathrm{D}}^{\prime}\end{array}$ & 2.1 & 1.1 & 1.8 \\
& 1.6 & 1.3 & 1.2
\end{tabular}

ratio which can then be used to calculate $k_{2}^{\prime}$. Finally, $k_{3}^{\prime}$ is obtained from the dependence of selectivity on time predicted by eq 10 .

Reaction rate constants $\left(k_{i, \mathrm{C}-\mathrm{H}}^{\prime}\right.$ and $\left.k_{i, \mathrm{C}-\mathrm{D}}^{\prime}\right)$ for $\mathrm{ODH}$ of undeuterated propane, perdeuterated propane, and propane-2, $2-d_{2}$, were obtained from the rate of initial propene formation using reaction mixtures containing $\mathrm{CH}_{3} \mathrm{CH}_{2} \mathrm{CH}_{3} / \mathrm{O}_{2}, \mathrm{CD}_{3} \mathrm{CD}_{2}$ $\mathrm{CD}_{3} / \mathrm{O}_{2}$, or $\mathrm{CH}_{3} \mathrm{CD}_{2} \mathrm{CH}_{3} / \mathrm{O}_{2}$. Kinetic isotope effects (defined as $k_{i, \mathrm{C}-\mathrm{H}}^{\prime} / k_{i, \mathrm{C}-\mathrm{D}}^{\prime}$ ratios) for the three reactions in Scheme 1 are shown in Table 2 . When using $\mathrm{C}_{3} \mathrm{H}_{8}$ and $\mathrm{C}_{3} \mathrm{D}_{8}$ as reactants, the kinetic isotope effect is greater than unity for all reactions, suggesting the involvement of $\mathrm{C}-\mathrm{H}$ bonds in kinetically relevant steps. Propane $\mathrm{ODH}$ and propene combustion show similar kinetic isotope effects (2.3 and 2.1, respectively) consistent with rate-determining initial $\mathrm{C}-\mathrm{H}$ bond activation steps for both reactions. These similar kinetic isotope effects suggest a kinetic resemblance between these two reactions that may include the requirements for similar active surface oxygen species. The kinetic isotope effect for propane combustion (1.6) is slightly lower than for propane dehydrogenation, suggesting that the formation of propene and $\mathrm{CO}_{x}$ from propane involves different active sites, as proposed previously. $4,5,13,25$

Propane and propene reactions involve the cleavage of $\mathrm{C}-\mathrm{H}$ bonds in kinetically relevant steps. There are two kinds of $\mathrm{C}-\mathrm{H}$ bonds in propane. The methyl $\mathrm{C}-\mathrm{H}$ bonds have a dissociation enthalpy of $420 \mathrm{~kJ} / \mathrm{mol}$, and the methylene $\mathrm{C}-\mathrm{H}$ bonds have a dissociation enthalpy of $401 \mathrm{~kJ} / \mathrm{mol}^{26}$ Kinetic isotope effect measurements using $\mathrm{CH}_{3} \mathrm{CH}_{2} \mathrm{CH}_{3}$ and $\mathrm{CD}_{3} \mathrm{CD}_{2} \mathrm{CD}_{3}$ cannot determine which $\mathrm{C}-\mathrm{H}$ bond is involved in the initial activation step. However, $\mathrm{CH}_{3} \mathrm{CD}_{2} \mathrm{CH}_{3}$ is expected to react more slowly than $\mathrm{CH}_{3} \mathrm{CH}_{2} \mathrm{CH}_{3}$ if methylene $\mathrm{C}-\mathrm{H}$ bonds are involved in the initial activation step. A similar rate for $\mathrm{CH}_{3} \mathrm{CD}_{2} \mathrm{CH}_{3}$ and $\mathrm{CD}_{3} \mathrm{CD}_{2} \mathrm{CD}_{3}$ would indicate that only methylene $\mathrm{C}-\mathrm{H}$ bonds are involved in the rate-determining step and that the isotopic identity of the rest of the propane molecule does not influence reaction rates. In turn, similar rates for $\mathrm{CH}_{3} \mathrm{CD}_{2} \mathrm{CH}_{3}$ and $\mathrm{CH}_{3} \mathrm{CH}_{2} \mathrm{CH}_{3}$ would indicate that only methyl $\mathrm{C}-\mathrm{H}$ bonds are involved in the rate-determining step. The data in Table 2 show that $\mathrm{CH}_{3} \mathrm{CD}_{2} \mathrm{CH}_{3}$ exhibits a normal $\mathrm{KIE}$ (with respect to $\mathrm{CH}_{3} \mathrm{CH}_{2} \mathrm{CH}_{3}$ ) for both propane dehydrogenation (1.7) and combustion (1.3). These values are smaller than those obtained when using $\mathrm{CD}_{3} \mathrm{CD}_{2} \mathrm{CD}_{3}$ and $\mathrm{CH}_{3} \mathrm{CH}_{2} \mathrm{CH}_{3}$ as isotopes (2.3 and 1.6 , respectively), but greater than unity, suggesting that $\mathrm{C}-\mathrm{H}$ bonds in both methyl and methylene groups can be involved in the rate-determining steps required for both propane dehydrogenation and combustion at these reaction conditions. These results differ from those obtained for $\mathrm{VO}_{x} / \mathrm{ZrO}_{2}$ at $593 \mathrm{~K}$ (propane dehydrogenation $\mathrm{KIE}$ of 2.8 for $\mathrm{CD}_{3} \mathrm{CD}_{2} \mathrm{CD}_{3}$, and $\mathrm{KIE}$ 2.7 for $\mathrm{CH}_{3} \mathrm{CD}_{2} \mathrm{CH}_{3}$ vs $\left.\mathrm{CH}_{3} \mathrm{CH}_{2} \mathrm{CH}_{3}\right){ }^{25}$ On $\mathrm{VO}_{x} / \mathrm{ZrO}_{2}$, KIE values clearly showed that only methylene $\mathrm{C}-\mathrm{H}$ bonds are involved in the rate-determining $\mathrm{C}-\mathrm{H}$ bond activation step. These differences in KIE values for $\mathrm{MoO}_{x}$ and $\mathrm{VO}_{x}$ catalysts may reflect mechanistic differences or merely the different reaction temperatures required for the two catalysts to reach 


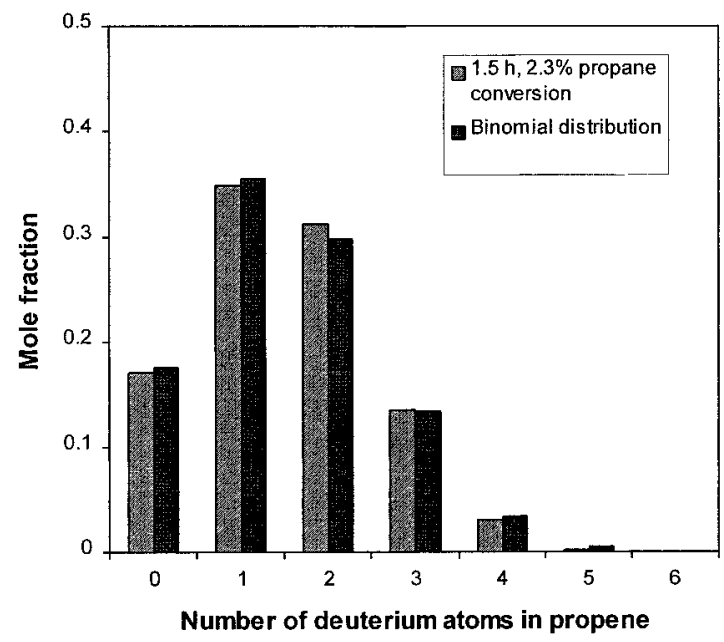

Figure 8. Deuterium distribution in propene formed from $\mathrm{C}_{3} \mathrm{H}_{8} / \mathrm{C}_{3} \mathrm{D}_{8} /$ $\mathrm{O}_{2}$ mixtures on $\mathrm{MoO}_{x} / \mathrm{ZrO}_{2}\left(688 \mathrm{~K}, 7.1 \mathrm{kPa}\right.$ of $\mathrm{C}_{3} \mathrm{H}_{8}, 7.1 \mathrm{kPa}$ of $\mathrm{C}_{3} \mathrm{D}_{8}$, $1.7 \mathrm{kPa}$ of $\mathrm{O}_{2}$, balance $\mathrm{He}$, gradientless batch reactor).

measurable turnover rates. As a result of the lower reactivity of $\mathrm{MoO}_{x}$ catalysts, the temperature of the KIE measurements was higher $(688 \mathrm{~K})$ than on $\mathrm{VO}_{x}$ catalysts $(593 \mathrm{~K})$. Such higher temperatures would tend to decrease the selectivity for activating one specific $\mathrm{C}-\mathrm{H}$ bond in propane, because bond energy difference for the two types of $\mathrm{C}-\mathrm{H}$ bonds in propane is only $19 \mathrm{~kJ} \mathrm{~mol}^{-1}$. Recent DFT calculations ${ }^{27}$ show that $\mathrm{C}-\mathrm{H}$ bonds in both methyl and methylene groups in propane can be activated on $\mathrm{V}_{2} \mathrm{O}_{5}$ species, but the activation energy for methyl $\mathrm{C}-\mathrm{H}$ bond reactions was much higher $\left(9.4 \mathrm{kcal} \mathrm{mol}^{-1}\right)$ than for the methylene $\mathrm{C}-\mathrm{H}$ bond $\left(14.5 \mathrm{kcal} \mathrm{mol}^{-1}\right)$. As a result, propene conversion pathways involving methyl $\mathrm{C}-\mathrm{H}$ group activation are much more sensitive to reaction temperature than the more facile paths involving methylene $\mathrm{C}-\mathrm{H}$ bonds. This would imply, in turn, that $\mathrm{KIE}$ values for $\mathrm{CH}_{3} \mathrm{CD}_{2} \mathrm{CH}_{3}$ vs $\mathrm{CH}_{3} \mathrm{CH}_{2} \mathrm{CH}_{3}$ should decrease with increasing temperature and the KIE observed for $\mathrm{CH}_{3} \mathrm{CD}_{2} \mathrm{CH}_{3}$ vs $\mathrm{CD}_{3} \mathrm{CD}_{2} \mathrm{CD}_{3}$ should rise with increasing temperatures. This is exactly the trend observed when KIE values on Mo-based catalysts at $688 \mathrm{~K}$ are compared with those the V-based catalysts at $593 \mathrm{~K}$. Thus, it appears unnecessary to propose a different activation selectivity for the two types of $\mathrm{C}-\mathrm{H}$ bonds in $\mathrm{VO}_{x}$ and $\mathrm{MoO}_{x}$ catalysts.

Kinetic isotopic effects for propene combustion on $\mathrm{MoO}_{x} /$ $\mathrm{ZrO}_{2}$ catalysts were also measured; they are shown in Table 2. Propene molecules contain three types of $\mathrm{C}-\mathrm{H}$ bonds. ${ }^{26}$ It is not possible, however, to determine which specific $\mathrm{C}-\mathrm{H}$ bond is cleaved in the rate-determining step for propene conversion to $\mathrm{CO}_{x}$ by simple inspection of KIE values using $\mathrm{CH}_{3} \mathrm{CD}_{2} \mathrm{CH}_{3} /$ $\mathrm{O}_{2}$ reactants. Figure 8 shows the deuterium distribution in propene during reactions of $\mathrm{C}_{3} \mathrm{H}_{8} / \mathrm{C}_{3} \mathrm{D}_{8} / \mathrm{O}_{2}$ mixtures. The binomial distribution of deuterium observed in propene at all chemical conversions shows that $\mathrm{H}$ is mobile on the catalyst surface and that multiple exchange of $\mathrm{C}_{3} \mathrm{H}_{6}$ and $\mathrm{C}_{3} \mathrm{D}_{6}$ with the surface adsorbed hydrogen $\left(\mathrm{OH}^{*} / \mathrm{OD}^{*}\right)$ pool occurs rapidly during ODH reactions, leading to a statistical distribution of $\mathrm{D}$ atoms in propene molecules, irrespective of the isotopic locations in the starting mixture. Therefore, propene formed from $\mathrm{CH}_{3} \mathrm{CD}_{2} \mathrm{CH}_{3} / \mathrm{O}_{2}$ contains $\mathrm{CH}_{3} \mathrm{CDCH}_{2}$, as well as all other isotopomers $\left(\mathrm{C}_{3} \mathrm{H}_{6-x} \mathrm{D}_{x}\right)$, and as a result the measured $\mathrm{KIE}$ reflects an average value for all possible propene isotopomers.

$\mathrm{H} / \mathrm{D}$ ratios in the propene formed from $\mathrm{C}_{3} \mathrm{H}_{8} / \mathrm{C}_{3} \mathrm{D}_{8} / \mathrm{O}_{2}$ mixtures confirm the relative rates of $\mathrm{C}-\mathrm{H}$ and $\mathrm{C}-\mathrm{D}$ bond activation. The H/D ratio in the reactant mixture is approximately 1 , but initial propene products have an H/D ratio

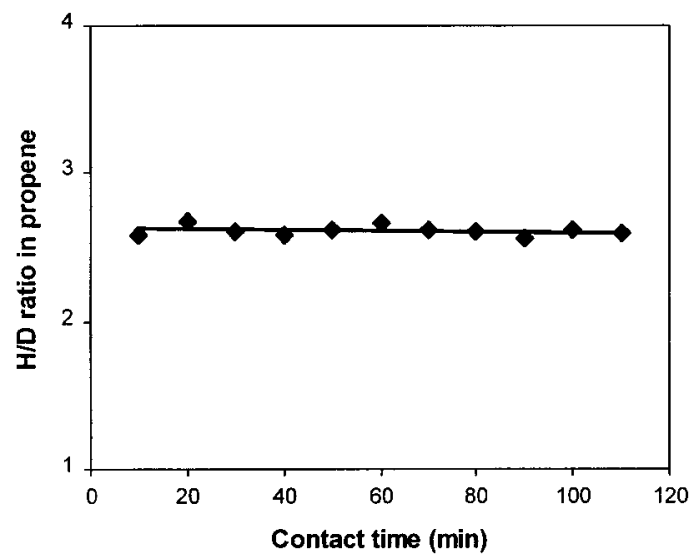

Figure 9. $\mathrm{H} / \mathrm{D}$ ratio in propene formed from $\mathrm{C}_{3} \mathrm{H}_{8} / \mathrm{C}_{3} \mathrm{D}_{8} / \mathrm{O}_{2}$ mixtures on $\mathrm{MoO}_{x} / \mathrm{ZrO}_{2}\left(688 \mathrm{~K}, 7.1 \mathrm{kPa}\right.$ of $\mathrm{C}_{3} \mathrm{H}_{8}, 7.1 \mathrm{kPa}$ of $\mathrm{C}_{3} \mathrm{D}_{8}, 1.7 \mathrm{kPa}$ of $\mathrm{O}_{2}$, balance $\mathrm{He}$, gradientless batch reactor).

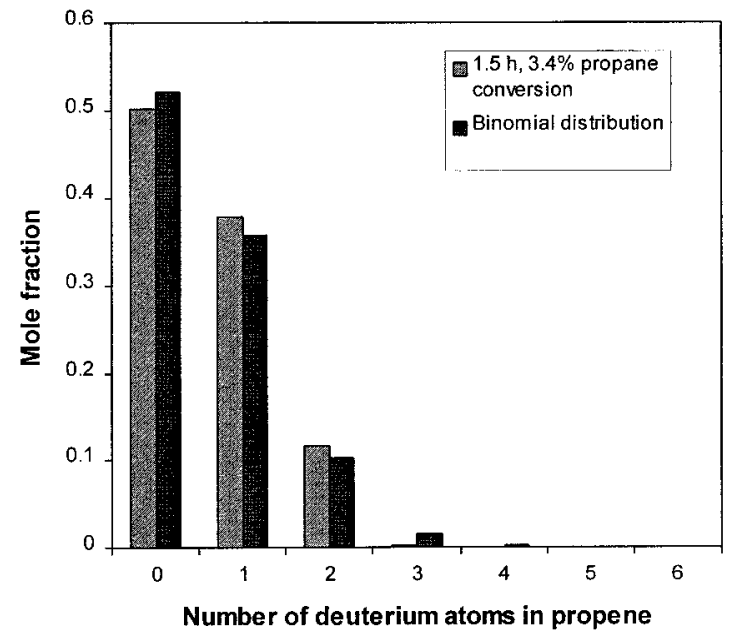

Figure 10. Deuterium distribution in propene formed from $\mathrm{C}_{3} \mathrm{H}_{8} / \mathrm{D}_{2} \mathrm{O} /$ $\mathrm{O}_{2}$ mixtures on $\mathrm{MoO}_{x} / \mathrm{ZrO}_{2}\left(688 \mathrm{~K}, 14.2 \mathrm{kPa}\right.$ of $\mathrm{C}_{3} \mathrm{H}_{8}, 0.5 \mathrm{kPa}$ of $\mathrm{D}_{2} \mathrm{O}$, $1.7 \mathrm{kPa}$ of $\mathrm{O}_{2}$, balance $\mathrm{He}$, gradientless batch reactor).

of 2.6 on $\mathrm{MoO}_{x} / \mathrm{ZrO}_{2}$ at all contact times between 0.1 and $2 \mathrm{~h}$ (Figure 9). This value is very similar to that obtained for the kinetic isotope effect (2.3) from the conversion of separate $\mathrm{C}_{3} \mathrm{H}_{8}-\mathrm{O}_{2}$ and $\mathrm{C}_{3} \mathrm{D}_{8}-\mathrm{O}_{2}$ mixtures to propene (Table 2).

Reversible Recombinative Desorption of $\mathrm{OH}$ Groups To Form Water. Water forms during propane ODH reactions and it inhibits propane reaction rates (Figure 5); therefore, the formation of water must involve a reversible elementary step. This effect of water is similar to that observed for propane reactions on $\mathrm{VO}_{x} / \mathrm{ZrO}_{2}{ }^{15}$ and for ethane reactions on $\mathrm{V}_{2} \mathrm{O}_{5} /$ $\mathrm{SiO}_{2}{ }^{23}$ The reversible nature of the recombinative desorption of $\mathrm{OH}$ groups to form water was confirmed from the Ddistribution in propene molecules formed on $\mathrm{MoO}_{x} / \mathrm{ZrO}_{2}$ from $\mathrm{C}_{3} \mathrm{H}_{8} / \mathrm{D}_{2} \mathrm{O} / \mathrm{O}_{2}$ or $\mathrm{C}_{3} \mathrm{D}_{8} / \mathrm{H}_{2} \mathrm{O} / \mathrm{O}_{2}$ mixtures. Neither mixture led to the formation of $\mathrm{C}_{3} \mathrm{H}_{x} \mathrm{D}_{8-x}(0<x<8)$ isotopomers in unreacted propane even at $\sim 2 \mathrm{~h}$ contact times $(\sim 4 \%$ propane conversion); this confirms that $\mathrm{C}-\mathrm{H}$ bond activation steps are irreversible. Binomial D-distributions were detected at all contact times in the propene molecules formed from either $\mathrm{C}_{3} \mathrm{H}_{8} / \mathrm{D}_{2} \mathrm{O} /$ $\mathrm{O}_{2}$ or $\mathrm{C}_{3} \mathrm{D}_{8} / \mathrm{H}_{2} \mathrm{O} / \mathrm{O}_{2}$ (Figure 10 ). These data show that water dissociatively adsorbs on $\mathrm{MoO}_{x}$ surfaces during propane $\mathrm{ODH}$, and that its microscopic reverse, the recombination of $\mathrm{OH}$ groups to form water during $\mathrm{ODH}$, is therefore a reversible step. The binomial D-distributions in propene from $\mathrm{C}_{3} \mathrm{H}_{8} / \mathrm{D}_{2} \mathrm{O} / \mathrm{O}_{2}$ or $\mathrm{C}_{3} \mathrm{D}_{8} /$ $\mathrm{H}_{2} \mathrm{O} / \mathrm{O}_{2}$ mixtures also suggest that $\mathrm{H}$ atoms formed from $\mathrm{C}-\mathrm{H}$ bonds in propane and from $\mathrm{O}-\mathrm{H}$ in water are mobile and that 


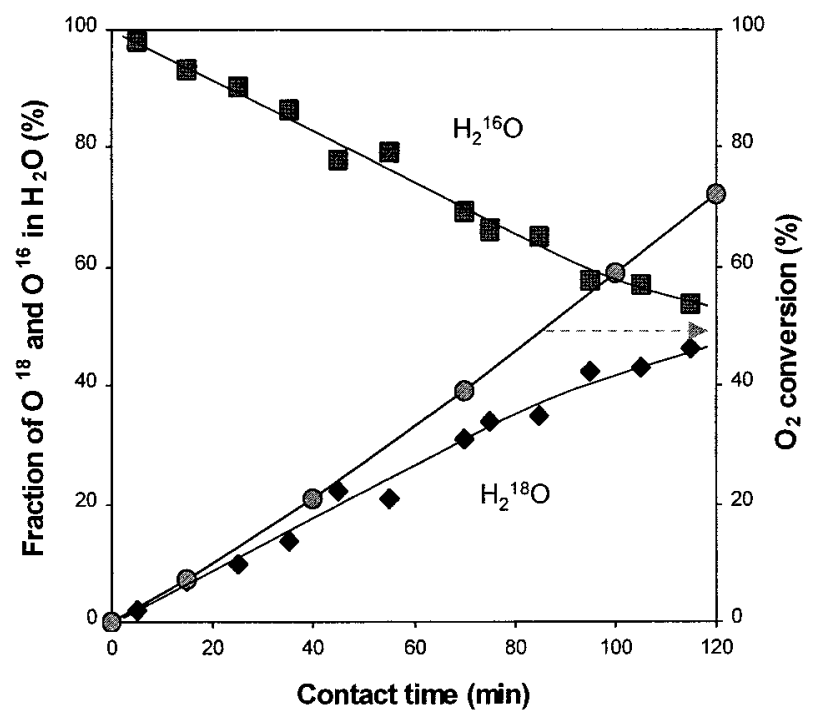

Figure 11. Fraction of ${ }^{18} \mathrm{O}$ and ${ }^{16} \mathrm{O}$ in $\mathrm{H}_{2} \mathrm{O}$ formed during reactions of ${ }^{18} \mathrm{O}_{2}-\mathrm{C}_{3} \mathrm{H}_{8}$ mixtures on $\mathrm{Mo}^{16} \mathrm{O}_{x} / \mathrm{Zr}^{16} \mathrm{O}_{2}\left(688 \mathrm{~K}, 14.2 \mathrm{kPa}\right.$ of $\mathrm{C}_{3} \mathrm{H}_{8}$, $1.7 \mathrm{kPa}$ of ${ }^{18} \mathrm{O}_{2}$, balance $\mathrm{He}$, gradientless batch reactor).

multiple exchange of $\mathrm{C}_{3} \mathrm{H}_{6}$ or $\mathrm{C}_{3} \mathrm{D}_{6}$ with this surface $\mathrm{OH}^{*} / \mathrm{OD}^{*}$ pool occurs during propane $\mathrm{ODH}$. These results are consistent with the assumption of quasi-equilibrated, recombinative desorption of $\mathrm{OH}$ groups (reaction 4), which was used in order to describe the inhibition of propane ODH by water. The form of the kinetic rate expression measured for propane $\mathrm{ODH}$ on $\mathrm{MoO}_{x}$ is more specifically consistent with the quasi-equilibration of this step.

Irreversible Oxygen Dissociation and Involvement of Lattice Oxygen Atoms. The rate of propane ODH over $\mathrm{MoO}_{x} /$ $\mathrm{ZrO}_{2}$ (in the absence of added water) is independent of the $\mathrm{O}_{2}$ concentration, suggesting that lattice oxygen atoms on a saturated surface are involved in this reaction, as also proposed by others. ${ }^{11-15}$ The involvement of lattice oxygen atoms was confirmed by carrying out propane $\mathrm{ODH}$ using ${ }^{18} \mathrm{O}_{2}$ on $\mathrm{Mo}^{16} \mathrm{O}_{x}$ measuring the relative concentrations of ${ }^{18} \mathrm{O}$ and ${ }^{16} \mathrm{O}$ in the $\mathrm{H}_{2} \mathrm{O}$ and $\mathrm{CO}_{x}$ products initially formed. Figure 11 shows the isotopic content in the $\mathrm{H}_{2} \mathrm{O}$ formed from ${ }^{18} \mathrm{O}_{2}-\mathrm{C}_{3} \mathrm{H}_{8}$ mixtures on $11 \mathrm{wt}$ $\% \mathrm{Mo}^{16} \mathrm{O}_{x} / \mathrm{Zr}^{16} \mathrm{O}_{2}$. Initially, water consists predominately of $\mathrm{H}_{2}{ }^{16} \mathrm{O}$, as expected if $\mathrm{C}_{3} \mathrm{H}_{8}$ reacted with lattice ${ }^{16} \mathrm{O}$ atoms in $\mathrm{Mo}^{16} \mathrm{O}_{x}$. As contact time increased, the $\mathrm{H}_{2}{ }^{18} \mathrm{O}$ concentration increased because ${ }^{16} \mathrm{O}$ atoms in the lattice are gradually replaced by ${ }^{18} \mathrm{O}$ from the ${ }^{18} \mathrm{O}_{2}$ in the gas phase. Figure $12 \mathrm{a}$ shows the isotopic distribution in $\mathrm{CO}_{2}$. Initially, the predominant isotopomer is $\mathrm{C}^{16} \mathrm{O}_{2}$, suggesting that lattice oxygen atoms are also required for the combustion reactions that form $\mathrm{CO}_{x}$. These results are consistent with those reported in the literature. ${ }^{15,28,29}$ Figure $12 \mathrm{~b}$ shows the isotopic content of $\mathrm{CO}_{2}$ as a function of reaction time. Similar to what is seen for $\mathrm{H}_{2} \mathrm{O}$, the percentage of ${ }^{16} \mathrm{O}$ decreases with the increase of contact time, while that of ${ }^{18} \mathrm{O}$ increases.

The reversibility of dissociative $\mathrm{O}_{2}$ chemisorption steps was probed by using ${ }^{18} \mathrm{O}_{2}-{ }^{16} \mathrm{O}_{2}-\mathrm{C}_{3} \mathrm{H}_{8}$ reactant mixtures and measuring the rate of formation of ${ }^{18} \mathrm{O}^{16} \mathrm{O}$ molecules, which can only arise from a reversible dissociation event. Reversible dissociative chemisorption of $\mathrm{O}_{2}$ would lead to rapid isotopic equilibration of ${ }^{16} \mathrm{O}_{2}$ and ${ }^{18} \mathrm{O}_{2}$ during $\mathrm{ODH}$ reactions; irreversible chemisorption steps would preserve the isotopic purity of the reactant mixture. Figure 13 shows the rates of propane and oxygen chemical conversion and the rate of formation of ${ }^{16} \mathrm{O}^{18} \mathrm{O}$ isotopomers on $\mathrm{Mo}^{16} \mathrm{O}_{x} / \mathrm{Zr}^{16} \mathrm{O}_{2}$ as a function of contact time. ${ }^{18} \mathrm{O}^{16} \mathrm{O}$ molecules are formed at a rate about 100 times smaller
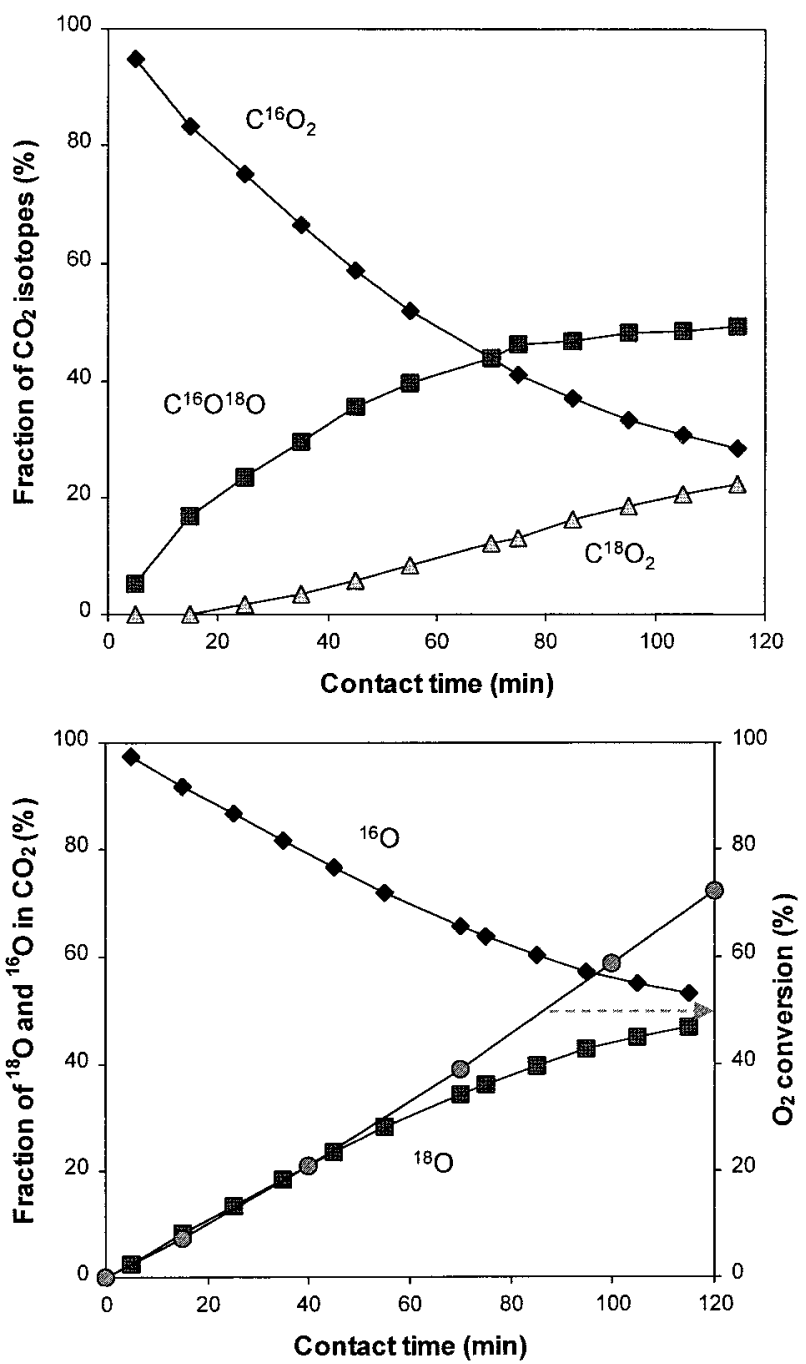

Figure 12. (a, top) Fraction of $\mathrm{CO}_{2}$ isotopes formed during reactions of ${ }^{18} \mathrm{O}_{2}-\mathrm{C}_{3} \mathrm{H}_{8}$ mixtures on $\mathrm{Mo}^{16} \mathrm{O}_{x} / \mathrm{Zr}^{16} \mathrm{O}_{2}\left(688 \mathrm{~K}, 14.2 \mathrm{kPa}\right.$ of $\mathrm{C}_{3} \mathrm{H}_{8}$, $1.7 \mathrm{kPa}$ of ${ }^{18} \mathrm{O}_{2}$, balance $\mathrm{He}$, gradientless batch reactor). (b, bottom) Fraction of ${ }^{18} \mathrm{O}$ and ${ }^{16} \mathrm{O}$ in $\mathrm{CO}_{2}$ formed during reactions of ${ }^{18} \mathrm{O}_{2}-\mathrm{C}_{3} \mathrm{H}_{8}$ mixtures on $\mathrm{Mo}^{16} \mathrm{O}_{x} / \mathrm{Zr}^{16} \mathrm{O}_{2}\left(688 \mathrm{~K}, 14.2 \mathrm{kPa}\right.$ of $\mathrm{C}_{3} \mathrm{H}_{8}, 1.7 \mathrm{kPa}$ of ${ }^{18} \mathrm{O}_{2}$, balance $\mathrm{He}$, gradientless batch reactor).

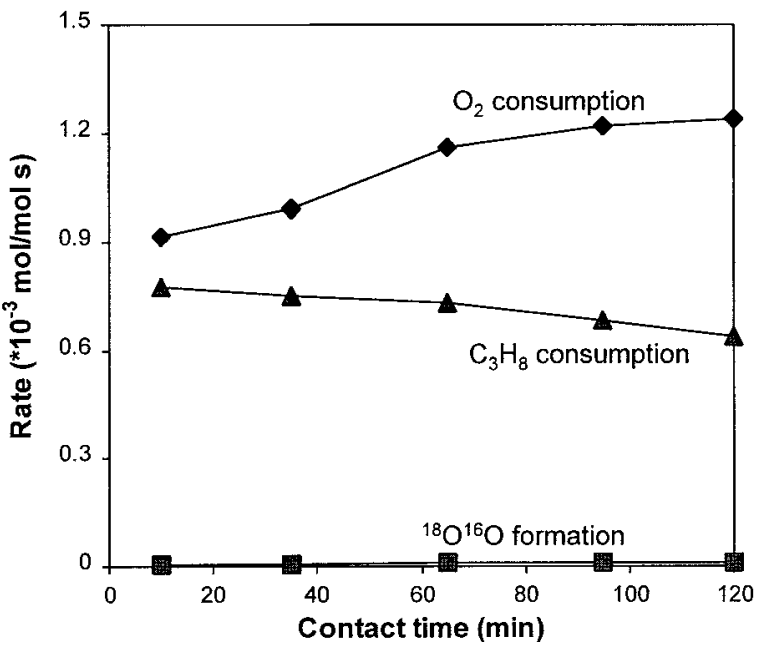

Figure 13. $\mathrm{C}_{3} \mathrm{H}_{8}$ and $\mathrm{O}_{2}$ consumption rates, and ${ }^{16} \mathrm{O}^{18} \mathrm{O}$ formation rates from ${ }^{18} \mathrm{O}_{2}-{ }^{16} \mathrm{O}_{2}-\mathrm{C}_{3} \mathrm{H}_{8}$ mixtures on $\mathrm{Mo}^{16} \mathrm{O}_{x} / \mathrm{Zr}^{16} \mathrm{O}_{2}(688 \mathrm{~K}, 14.2 \mathrm{kPa}$ of $\mathrm{C}_{3} \mathrm{H}_{8}, 0.85 \mathrm{kPa}$ of ${ }^{18} \mathrm{O}_{2}, 0.85 \mathrm{kPa}$ of ${ }^{16} \mathrm{O}_{2}$, balance He, gradientless batch reactor).

than the rate at which propane or oxygen are consumed by chemical reactions. Trace amounts of ${ }^{18} \mathrm{O}^{16} \mathrm{O}$ are only observed 
after a contact time of $\sim 2 \mathrm{~h}$ (at $\sim 70 \% \mathrm{O}_{2}$ conversion). This suggests that dissociative $\mathrm{O}_{2}$ chemisorption steps (step 5) required in propane $\mathrm{ODH}$ are irreversible at the conditions of these experiments.

Since $\mathrm{O}_{2}$ dissociation is irreversible and ${ }^{16} \mathrm{O}^{18} \mathrm{O}$ molecules do not form during reactions of ${ }^{18} \mathrm{O}_{2}-\mathrm{C}_{3} \mathrm{H}_{8}$ mixtures on $\mathrm{Mo}^{16} \mathrm{O}_{x}$ / $\mathrm{Zr}^{16} \mathrm{O}_{2}$, the amount of ${ }^{16} \mathrm{O}$ coming from lattice oxygen can be calculated from $\mathrm{O}_{2}$ conversion and ${ }^{16} \mathrm{O}$ concentration in products $\mathrm{CO}_{x}$ and $\mathrm{H}_{2} \mathrm{O}$. The total amount of ${ }^{16} \mathrm{O}$ in the $\mathrm{Mo}^{16} \mathrm{O}_{3}$ phase supported on $\mathrm{ZrO}_{2}$ is $80 \mu \mathrm{mol}$ (calculated from $\mathrm{MoO}_{3}$ concentration and amount of catalyst used). At $70 \% \mathrm{O}_{2}$ conversion, the ${ }^{16} \mathrm{O}$ fraction in water and $\mathrm{CO}_{x}$ products is 0.5 ; this corresponds to $191 \mu \mathrm{mol}{ }^{16} \mathrm{O}$ in the products, which must have come from the lattice. This value exceeds the number of lattice oxygens in the supported $\mathrm{MoO}_{x}$ phase $(80 \mu \mathrm{mol})$, but it is much smaller than the total amount of ${ }^{16} \mathrm{O}$ available in the $\mathrm{MoO}_{3}$ and $\mathrm{ZrO}_{2}(587 \mu \mathrm{mol})$ components of the catalyst. Therefore, lattice oxygens in both the $\mathrm{MoO}_{x}$ active phase and the $\mathrm{ZrO}_{2}$ support exchange rapidly during propane $\mathrm{ODH}$ reactions at $688 \mathrm{~K}$. Consequently, lattice oxygens from both $\mathrm{MoO}_{3}$ and $\mathrm{ZrO}_{2}$ support are ultimately used in propane reactions.

\section{Conclusions}

Oxidative dehydrogenation of propane on $\mathrm{MoO}_{x} / \mathrm{ZrO}_{2}, \mathrm{MoO}_{3} /$ $\mathrm{ZrO}_{2}$, and $\mathrm{ZrMo}_{2} \mathrm{O}_{8} / \mathrm{ZrO}_{2}$ catalysts occurs via parallel and sequential oxidation steps. Propene is the most abundant primary product. $\mathrm{CO}$ and $\mathrm{CO}_{2}$ form via either secondary combustion of propene, or by direct combustion of propane. The dependences of reaction rates on $\mathrm{C}_{3} \mathrm{H}_{8}, \mathrm{O}_{2}$, and $\mathrm{H}_{2} \mathrm{O}$ concentrations are identical on supported $\mathrm{MoO}_{x}, \mathrm{MoO}_{3}$, and $\mathrm{ZrMo}_{2} \mathrm{O}_{8}$ powders, suggesting that similar active centers are present on these catalysts surfaces. The reaction kinetics are consistent with a Mars-van Krevelen redox sequence in which lattice oxygen atoms participate in the irreversible activation of $\mathrm{C}-\mathrm{H}$ bonds in propane. The resulting alkyl species desorb as propene and the remaining $\mathrm{OH}$ groups recombine to form water and reduced Mo centers. These reduced Mo centers reoxidize by irreversible dissociative chemisorption of $\mathrm{O}_{2}$. The recombination of $\mathrm{OH}$ groups to form water is reversible. The assumption that surface oxygen and $\mathrm{OH}$ groups are the most abundant surface intermediates leads to a rate expression that describes accurately the measured kinetics of propane ODH reactions. Isotopic tracer studies fully confirm the assumptions required in order to describe the observed effects of reactant and product concentrations on the rate of propane ODH reactions.

Acknowledgment. This work was supported by the Director, Office of Energy Sciences, Chemical Sciences Division of the U.S. Department of Energy under Contract DE-AC03-76SF00098.

\section{References and Notes}

(1) Blasko, T.; López Nieto, J. M. Appl. Catal. A 1997, 157, 117.

(2) Kung, H. H. Adv. Catal. 1994, 40, 1.

(3) Albonetti, S.; Cavani, F.; Trifiro, F. Catal. Rev.-Sci. Eng. 1996, $38,413$.

(4) Chen, K.; Xie, S.; Iglesia, E.; Bell, A. T. J. Catal. 2000, 189, 421

(5) Khodakov, A.; Yang, J.; Su, S.; Iglesia, E.; Bell, A. T. J. Catal. 1998, 177, 343 .

(6) Centi, G.; Triffiro, F. Appl. Catal. A 1996, 143, 3.

1.

(7) Mamedov, E. A.; Cortés-Corberan, V. Appl. Catal. A 1995, 127,

(8) Grasselli, R. K.Catal. Today 1999, 49, 141.

(9) Andersson, S. L. T. Appl. Catal. A 1994, 112, 209.

(10) Michaels, J. N.; Stern, D. L.; Grasselli, R. K. Catal. Lett. 1996, $42,135$.

(11) Michaels, J. N.; Stern, D. L.; Grasselli, R. K. Catal. Lett. 1996, 42,139 .

(12) Creaser, D.; Andresson, B. Appl. Catal. A 1996, 141, 131.

(13) Stern, D. L.; Grasselli, R. K. J. Catal. 1997, 167, 560.

(14) Sautel, M.; Thomas, G.; Kaddouri, A.; Mazzocchia, C.; Anouchinsky, R. Appl. Catal. A 1997, 155, 217.

(15) Chen, K.; Khodakov, A.; Yang, J.; Bell, A. T.; Iglesia, E. J. Catal. 1999, 186,325 .

(16) Jacky, A. Y.; Chen, K.; Bell, A. T.; Iglesia, E. J. Catal. 1999, 188, 132.

(17) Iglesia, E.; Baumgartner, J. E.; Price, G. L. J. Catal. 1992, 134, 549.

(18) Price, G. L.; Iglesia, E. Ind. Eng. Chem. Res. 1989, 28, 839.

(19) Biscardi, J. A.; Iglesia, E. Catal. Today 1996, 31, 207.

(20) Biscardi, J. A.; Iglesia, E. J. Catal. 1999, 182, 117.

(21) Iglesia, E.; Baumgartner, J. E. Catal. Lett. 1993, 21, 55.

(22) Meitzner, G. D.; Iglesia, E.; Baumgartner, J. E.; Huang, E. S. J. Catal. 1993, 140, 209.

(23) Oyama, S. T.; Middlebrook, A. M.; Somorjai, G. A. J. Phys. Chem. 1990, 94, 5029

(24) Chen, K.; Xie, S.; Iglesia, E.; Bell, A. T. Unpublished results.

(25) Chen, K.; Iglesia, E.; Bell, A. T. J. Catal. 2000, 192, 197.

(26) CRC Handbook of Chemistry and Physics, 71st ed.; CRC Press: Boca Raton, FL, 1990; pp 9-95.

(27) Gilardoni, F.; Bell, A. T.; Chakraborty, A. K. J. Phys. Chem. B, in press.

(28) Martim, D.; Kaur, P.; Duprez, D.; Gaigneaux, E.; Ruiz, P.; Delmon, B.Catal. Today 1996, 32, 329.

(29) Ono, T.; Nakajo, T.; Hironaka, T. J. Chem. Soc., Faraday Trans. 1990, 86, 4077. 